\title{
The Application of the Jigsaw Cooperative Learning Technique in Mapping Concepts of Nuclear Radiation in Diagnosis and Therapy
}

\author{
Abdallah Ahmad Atallah, Mohamed Fahmi Ben Hassen and Abdallah Bashir Musa \\ Department of Basic Sciences, Deanship of Preparatory Year and Supporting \\ Studies, Imam Abdulrahman Bin Faisal University, Saudi Arabia \\ https://orcid.org/0000-0002-0628-9074 \\ https:// orcid.org/0000-0002-9713-3824 \\ https://orcid.org/0000-0002-1649-2391 \\ Mohamed Redha Bougherira \\ Department of Self-Development, Deanship of Preparatory Year and Supporting \\ Studies, Imam Abdulrahman Bin Faisal University, Saudi Arabia \\ https:// orcid.org/0000-0002-1864-8134 \\ Najla Frih \\ Department of Basic Sciences, Deanship of Preparatory Year and Supporting \\ Studies, Imam Abdulrahman Bin Faisal University, Saudi Arabia \\ https://orcid.org/0000-0002-3125-9993
}

\begin{abstract}
Physics for medical students is perceived as a sophisticated subject. The sophistication, however, does not lie in the physics concepts themselves or students' comprehension of the subject, but it is more often related to the ineffectiveness of techniques applied to teach the subject. This study investigates the effect of the Jigsaw technique, a highly structured form of cooperative learning, on the academic achievement of first-year medical students in learning physics. A quasi-experimental research approach with a pretest-posttest design was employed to conduct the study with a purposive randomly selected sample of fifty students made up of twenty-five students in the control group and twenty-five students in the experimental group. The control group was taught using traditional lectures, while the experimental group was taught using the Jigsaw technique which involved students working actively to map the concepts of nuclear radiation in diagnosis and therapy. A comprehensive statistical analysis, which included a Shapiro's test, paired sample t-test, independent sample t-test, average gain factor, and size effect calculations, was used to test the research hypotheses. The findings of this study showed that there was a statistically significant difference $(\mathrm{P}<0.05)$ between the post-test scores of students exposed to the Jigsaw cooperative learning technique and those who were not. In addition, it was deduced
\end{abstract}


by the educator (first author) that the students were actively engaged with the topic material, took more responsibility for their performance in the activity, learned how to map the radiation physics concepts, and explored a new learning environment that enabled them to use their higher-order thinking skills to solve medical physics problems.

Keywords: first-year; medical students, radiation; Jigsaw; cooperative learning; concept map

\section{Introduction}

First-year students in medical colleges consider physics troublesome in comparison with other basic sciences such as biology, chemistry and even mathematics since they are required to process various forms of information, such as experimental results, equations, calculations, figures, and scientific interpretations, at the same time (Zafer \& Mustafa, 2008; Gelu \& Muza, 2011; Maija, 2012; Márquez et al., 2017). In the field of medicine, physics explains many principles that govern the functions of the human body. For example, it helps in understanding applications for ultrasound, blood pressure and viscosity (Knight et al., 2019), electrical activity of the brain, electrical and muscular functions of the heart, electrical signaling of nerves and their insulation (Lodish et al., 2000), X-ray imaging (Kemerink et al., 2012), as well as the use of radionuclides in diagnostic and therapeutic medicine (Yeong et al., 2014).

However, several researchers agree that students commonly find physics challenging to learn (Angell et al., 2007). It has also been suggested that the challenge does not lie in the complexity of the physics concepts or the perception of the subject held by students, but, more often, in the ineffectiveness of techniques applied to teach the subject (Redish, 1994; Redish \& Steinberg, 1999). Scientific societies around the world are racing to improve their educational systems through solid grounding in knowledge and learning. Superior educational systems have noted that active-learning is an advantageous teaching-learning technique for interdisciplinary topics, especially in physics (Alraddadi, 2010; Aydin \& Biyikli, 2017; Márquez et al., 2017).

Equally, educators have recognized cooperative learning as one of the most effective strategies for helping learners to overcome the learning challenges associated with complex subjects such as physics (Dong et al., 2019). The evolution of interest in cooperative learning techniques gained momentum in the 1990s due to the shift away from traditional teaching techniques to more active student-centered techniques (McCabe \& O'Connor, 2013). This evolution has given rise to different cooperative teaching techniques which can be implemented by educators to transfer knowledge and develop learners' skills. As opposed to traditional methods, learners are encouraged to use problemsolving and critical thinking skills, apply their learning, and share it with their peers independently. In this respect, learning activities such as presentations, debates, brainstorming, case-studies, Jigsaw, group discussions, hands-on activities, problem solving, experiential learning and simulations have the potential to provide learners with opportunities to develop more profound 
levels of understanding, which are required for cumbersome concepts (Asoodeh et al., 2012).

Aronson et al. (1978) developed the Jigsaw technique in the early 1970s. It has been attracting the attention of educators and educational researchers for the last few decades (Walker et al., 2015). In essence, the technique seeks to promote collaboration between learners, to dispel the negative learning competition between them, to promote their higher order thinking skills, and to help them during their learning experience and future professional careers (Eachempati et al., 2017). Furthermore, it is a successful learning technique for small mixedabilities groups to improve their understanding of a specific scientific topic and requires learners to take responsibility for their own learning and the learning of their peers, which leads to the promotion of cooperation and a sense of shared achivement, interdependnce, individual accountability, and the development of interpersonal and team skills (Jones \& Jones, 2008).

\section{Literature Review}

Several studies have shown that active learners are better than their passive peers in recalling and assimilating concepts. Zafer and Mustafa (2008) analyzed improvements in academic performance and retention of knowledge among graduate students in magnetism by employing the Jigsaw technique with an experimental group and traditional teaching methods with a control group. The study revealed that a statistically significant difference was detected in favor of the experimental group showing the effectiveness of the highly structured cooperative learning-teaching sequence. Within the same circumstances, Gelu and Muza (2011) applied the Jigsaw technique to deliver the fundamental concepts of Bohr's model of the hydrogen atom and its extrapolation to other atoms with more electrons; they concluded that cooperative learning strengthens the basic knowledge of students of atomic physics and enhances their communication skills. Pelobillo (2018) delineated the effectiveness of the Jigsaw technique in problem-solving and mastering the concepts of physics among high school students, concluding that students' exposure to the Jigsaw technique improved physics learning. Gamit et al. (2017) also studied the effect of cooperative learning - through small group activities - in enhancing the performance level of mathematics students; they concluded that the abilities of the students and their learning habits were improved as a result of cooperative activities more than by traditional methods.

Karacop and Doymus (2013) investigated the effect of the Jigsaw cooperative learning technique on the perception of first-year university students of chemical bonding and their conceptions of the particulate nature of matter. It concluded that students should take part in interactive group work rather than studying alone and at the same time, they should be assisted by animations. Within this framework, students can favorably digest chemistry modules at the macroscopic, microscopic, and symbolic levels. Kumar et al. (2017) assessed the improvement in medical students' cognitive skills for microbiology by implementing the Jigsaw technique. The findings showed that the technique led to results which were substantially better than the results from traditional 
classroom teaching since peers shared their knowledge and understanding to construct the concepts of the specific topic, and then strengthened them with one another.

Aliya et al. (2019) conducted a cross-sectional study to analyse the learning experience of biochemistry students using the Jigsaw cooperative learning technique and to explore students' opinions of it. They revealed that the majority of students had a positive attitude towards Jigsaw and acknowledged the benefits of it, specifically in terms of the communication skills it involved.

Given what has been said, meaningful, and well-organized content knowledge is required to formulate high standard learning and teaching techniques (Chiou, 2008). Within this context, portraying knowledge is based on concept maps where knowledge is organized and represented graphically as connected concepts, laws, or other forms of conceptual knowledge (Chiou, 2008; Collins \& Nyenhius, 2020). The benefit of concept maps is that they provide a comprehensible visualization of how concepts are connected to each other by links and can therefore be used to picture the interconnectedness of knowledge structures (Martínez et al., 2012). Maija (2012) found that concept mapping consolidates the knowledge structure, which helps students to comprehend the procedural nature of the connections between physics concepts and helps to foster reflective thinking during the learning process. Mustafa and Talat (2013) studied the effectiveness of the concept mapping strategy as an instructional tool for teaching chemistry; they concluded that a concept map works better in the field of education, taking another step forward towards instructional techniques, and making learning easier for learners. Márquez et al. (2017) analyzed the effect of the Jigsaw technique on academic achievement in physics subjects. In their study, an experimental group worked on constructing concept maps using the Jigsaw technique, while a control group worked on the same subject using a lecture-based learning technique. The results showed that without achieving considerable statistical significance, the learning sequence of the experimental group was improved. The students were encouraged to work purposefully in the Jigsaw groups, despite the perception of a sense of insecurity due to a new activity that they had not been exposed to before. Recently, Baliga et al. (2021) stated that the use of concepts maps were effective teaching and learning tool for medical students and excellent way to assess their critical thinking skills.

\section{Ready-to-Go Teaching Modules}

Cooperative learning techniques in teaching physics for the health track students in the Deanship of Preparatory year (DPY) at Imam Abdulrahman Bin Faisal University (IAU), Kingdom of Saudi Arabia (KSA) were introduced to teaching in 2013. To successfully integrate active learning techniques within the classroom, the department of basic sciences of the DPY, has been using Pearson's Ready-to-Go Teaching Modules (R-to-GTMs) (Pearson, MyLab and Mastering, 2019) for the last few years. These modules support physics educators to transform the educational experience and present information in impactful ways, based on the most recent research, and find the best assets to use before, during, and after class (Ozdemir \& Öner, 2015; Kim, 2017). The modules have been utilized in teaching fundamentals of physics for the health track students in 
medicine, dentistry, pharmacy, applied medical sciences, nursing, and public health. It is worth mentioning that these interactive modules assist students and educators to be organized and easily engage with scientific content and each other (Brady \& O'Reilly, 2020).

\section{Research Question and Hypotheses}

Because of their multiple pedagogical advantages, the Jigsaw cooperative learning and concept mapping techniques have been used extensively in teaching humanitarian and scientific courses to high school students and undergraduate students: first-years, juniors, and seniors (Connell et al., 2016; Karacop, 2017). The literature includes significantly fewer educational studies on the use of Jigsaw in teaching physics for medical students. Thus, this study was conducted to shed more light on the effect of implementing the Jigsaw cooperative learning technique on medical students' achievement in physics at IAU, KSA through mapping the concepts of nuclear radiation in diagnostic and therapeutic medicine. Besides, it could serve as a pull trigger to motivate researchers to develop novel online models, especially during the Covid-19 pandemic, to study the effect of using the Jigsaw technique on the students' perception of multidisciplinary scientific topics. Built on the usefulness of using Jigsaw technique that was highlighted significantly in the literature review of this study, and the indispensable need for well-thought-out learning-teaching procedure, this study addresses the following research question:

- Is the application of the Jigsaw cooperative learning technique effective in improving first-year medical students' academic achievement in physics?

Based on the above-mentioned question, the following four null hypotheses (NHs) are formulated:

- $\quad$ NH_1: There is no statistically significant difference between mean pre-test achievement scores of the students who were taught by the Jigsaw cooperative learning technique and those were taught by the traditional learning technique.

- NH_2: There is no statistically significant difference between mean achievement scores of the control group students from the pre-test to the post-test.

- NH_3: There is no statistically significant difference between the mean academic achievement scores of the experimental group students from the pre-test to the post-test.

- NH_4: There is no statistically significant difference between the mean posttest achievement scores of the students who were taught by the Jigsaw cooperative learning technique and those were taught by the traditional learning technique.

\section{Methodology of the Research}

This section includes the research design, research subjects, research instruments, procedures, and statistical treatment.

\subsection{Sample}

A quasi-experimental approach with a pretest-posttest design was employed to conduct the study. The sample of the study consisted of fifty health-track male students, who were randomly selected from the physics course population and 
taught by the researcher (first author) in the DPY at IAU in the 2019-2020 academic year. The students were divided into two groups consisting of twentyfive students in the control group and twenty-five students in the experimental group. The control group was exposed to traditional lectures, in which the educator acts as a knowledge dispenser rather than a learning facilitator. In contrast, the experimental group was taught through the Jigsaw technique, in which the educator acts as a facilitator and organizer providing resources and support to the students, and the students must work actively in a purposeful way.

\subsection{Pre-test and Post-test}

The present study was made up of three phases. Phase I (pre-testing) and Phase II (Jigsaw cooperative learning versus traditional lectures) are explained in Table 1. Phase III (post-testing) is explained in Table 2.

Table 1: Schematic view of pre-testing phase and Traditional lectures versus Jigsaw cooperative learning phase

\begin{tabular}{|c|c|c|c|c|}
\hline \multirow{2}{*}{ Phase } & \multicolumn{2}{|c|}{ Groups } & \multirow{2}{*}{$\begin{array}{l}\text { Number of } \\
\text { Sessions }\end{array}$} & \multirow{2}{*}{$\begin{array}{l}\text { Time } \\
\text { (in hr) }\end{array}$} \\
\hline & Control Group X & Experimental Group Y & & \\
\hline \multirow{4}{*}{ 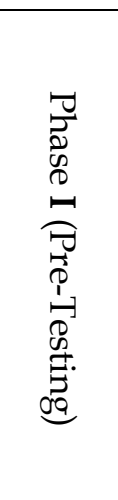 } & $\begin{array}{l}\text { Academic achievement } \\
\text { in physics }\end{array}$ & $\begin{array}{l}\text { Academic achievement } \\
\text { in physics }\end{array}$ & \multirow[b]{2}{*}{$\begin{array}{l}\text { In-class Test } \\
\text { (Pre-test) }\end{array}$} & \multirow{2}{*}{1} \\
\hline & \multicolumn{2}{|c|}{$\begin{array}{l}\text { Both groups took a pertest to ensure they were matched } \\
\text { in their literacy }\end{array}$} & & \\
\hline & Educator-centered technique & Student-centered technique & & \\
\hline & $\begin{array}{l}\text { The students made use of } \\
\text { the pre-class contents to } \\
\text { prepare for the physics } \\
\text { classes. The contents were } \\
\text { posted on the blackboard } \\
\text { system of IAU. }\end{array}$ & $\begin{array}{l}\text { The students made use of } \\
\text { the pre-class contents to } \\
\text { prepare for the physics } \\
\text { activity. The contents were } \\
\text { posted on the blackboard } \\
\text { system of IAU. }\end{array}$ & $\begin{array}{c}\text { Preparation at } \\
\text { home }\end{array}$ & - \\
\hline 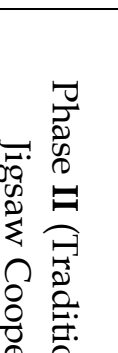 & $\begin{array}{l}\text { The educator delivered a } \\
\text { traditional session on the } \\
\text { specified topic and the } \\
\text { students exclusively } \\
\text { listened. During activities, } \\
\text { students worked alone, and } \\
\text { collaboration was } \\
\text { discouraged. }\end{array}$ & $\begin{array}{l}\text { The educator delivered an } \\
\text { interactive session on the } \\
\text { topic being studied via } \\
\text { stimulating the student } \\
\text { higher order thinking skills } \\
\text { and preparing them for the } \\
\text { upcoming cooperative } \\
\text { sessions. }\end{array}$ & $\begin{array}{c}\text { One } \\
\text { classroom } \\
\text { session }\end{array}$ & 1 \\
\hline 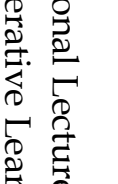 & $\begin{array}{l}\text { The educator continued } \\
\text { delivering the specified } \\
\text { topic and responded to the } \\
\text { students' questions. }\end{array}$ & $\begin{array}{l}\text { Forming Jigsaw groups } \\
\text { (each student in the Jigsaw } \\
\text { group was assigned to lean } \\
\text { one section of the topic) }\end{array}$ & $\begin{array}{c}\text { One } \\
\text { classroom } \\
\text { session }\end{array}$ & 1 \\
\hline 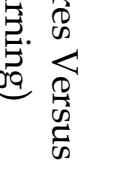 & $\begin{array}{l}\text { The educator continued } \\
\text { delivering the specified } \\
\text { topic with some examples } \\
\text { and the students took notes. }\end{array}$ & $\begin{array}{l}\text { Forming expert groups } \\
\text { (each expert group was } \\
\text { assigned to construct the } \\
\text { concept map of one section). }\end{array}$ & $\begin{array}{c}\text { One } \\
\text { classroom } \\
\text { session }\end{array}$ & 1 \\
\hline
\end{tabular}




\begin{tabular}{|l|l|l|c|c|}
\hline $\begin{array}{l}\text { The educator displayed } \\
\text { some videos and animation } \\
\text { and solved some real-world } \\
\text { problems in nuclear } \\
\text { radiation. }\end{array}$ & $\begin{array}{l}\text { Students returned to their } \\
\text { Jigsaw groups and each } \\
\text { group was assigned to } \\
\text { construct the whole concept } \\
\text { map of the topic. }\end{array}$ & $\begin{array}{c}\text { One } \\
\text { classroom } \\
\text { session }\end{array}$ & $\mathbf{1}$ \\
\hline $\begin{array}{l}\text { The educator continued } \\
\text { delivering the specified } \\
\text { topic and clarified students' } \\
\text { misconceptions. }\end{array}$ & $\begin{array}{l}\text { The full concept-map was } \\
\text { constructed } \\
\text { (Educator-learner interactive } \\
\text { session) }\end{array}$ & $\begin{array}{c}\text { One } \\
\text { classroom } \\
\text { session }\end{array}$ & $\mathbf{2}$ \\
\hline
\end{tabular}

Table 2: Schematic view of the post-testing phase

\begin{tabular}{|c|c|c|c|c|}
\hline \multirow[t]{2}{*}{ Phase } & \multicolumn{2}{|c|}{ Groups } & \multirow{2}{*}{$\begin{array}{l}\text { Number of } \\
\text { Sessions }\end{array}$} & \multirow{2}{*}{$\begin{array}{c}\text { Time } \\
\text { (in hr) }\end{array}$} \\
\hline & Control Group X & Experimental Group Y & & \\
\hline \multirow{3}{*}{ 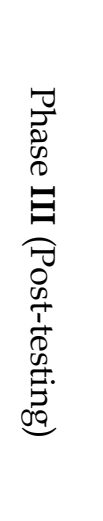 } & $\begin{array}{l}\text { The students were assigned } \\
\text { to solve some selected end of } \\
\text { chapter questions and } \\
\text { problems from the } \\
\text { recommended textbook. }\end{array}$ & $\begin{array}{l}\text { The students solved the } \\
\text { adaptive follow-up } \\
\text { assignment items on } \\
\text { Pearson's MyLab and the } \\
\text { Mastering platform. }\end{array}$ & Homework & - \\
\hline & $\begin{array}{l}\text { Measurement of academic } \\
\text { achievement in physics }\end{array}$ & $\begin{array}{l}\text { Measurement of academic } \\
\text { achievement in physics }\end{array}$ & & \\
\hline & \multicolumn{2}{|c|}{$\begin{array}{l}\text { Both groups took a post-test to measure their } \\
\text { achievement in the physics course. } \\
\text { At the end of the test, each student in the two groups } \\
\text { wrote his reflection on the conducted learning } \\
\text { technique. }\end{array}$} & $\begin{array}{l}\text { In-class test } \\
\text { (post-test) }\end{array}$ & 1 \\
\hline
\end{tabular}

The control and experimental groups were given a pre-test at the beginning and a post-test at the end of the study. Each test was composed of twenty multiplechoice questions in which each correct answer received 0.5 points. A pre-test was administrated to both groups to find the level of academic performance of each student in physics. The result for this served as the independent variable for comparing the results of the assessment after the intervention had been conducted (Aydin \& Biyikli, 2017). It served as the baseline to indicate how the students improved after applying the cooperative Jigsaw technique. In Phase II, the activity was performed by the students in the experimental group and the educator acted only as a learning facilitator. In contrast, the control group was exposed to a sequence of traditional lectures. The post-testing phase was undertaken to assess the progress of the students' learning in physics.

\subsection{Procedure}

The present study demonstrates the considerable significance of using the Jigsaw cooperative learning and concept map for students' academic achievement. A concept map is a type of graphic organizer used to help students organize and represent knowledge on a subject. A concept map begins with a main idea and then forks to showcase how that main idea can be divided into specific topics (Yatimah et al., 2020). Likewise, Jigsaw is a well-structured cooperative learning technique, which has been successfully used by numerous educational systems to improve academic achievement among students (Karacop \& Doymus, 2013). This technique assigns students to groups that are 
composed of individuals with varying skill levels. Each group member is responsible for becoming an expert on one section of the topic being studied and then teaching it to the other members of the group. The Jigsaw technique was implemented in the present study as follows:

1. The experimental group $Y\left(\mathrm{~N}_{Y}=25\right)$ was divided into five "Jigsaw groups", which were labeled JG 1, JG 2, JG 3, JG 4 and JG 5, respectively. Each Jigsaw group was composed of five students and was diverse in terms of ethnicity, race, and ability. The students in the five Jigsaw groups were labeled respectively as: JG 1: A1, A2, A3, A4, and A5, JG 2: B1, B2, AB, B4, and B5, JG 3: C1, C2, C3, C4, and C5, JG 4: D1, D2, D3, D4, and D5, and JG 5: E1, E2, E3, E4, and E5.

2. The "nuclear radiation" topic was divided into five sections: radioactivity, biological effects of radiation, diagnostic radiation, therapeutic radiation, and radiation dose, which were labeled S1, S2, S3, S4 and S5, respectively. It was ensured that the content of one section was not a prerequisite for any of the other sections.

3. Each student in a Jigsaw group was assigned to learn one of the five sections: S1, S2, S3, S4 and S5. The students were given enough time to read over their assigned sections and each student had direct access only to his own section. Each student was encouraged to start constructing the corresponding concept map of his assigned section.

4. Five "expert groups" were then formed. One student from each Jigsaw group joined other students assigned to the same section. The expert groups were labeled EG 1, EG 2, EG 3, EG 4, and EG 5, respectively. Enough time was given to the students in each expert groups to discuss the main points of their section and to construct the corresponding visual concept map, which was to be presented to their Jigsaw group. The students in the five expert groups were labeled respectively as: EG 1: A1, B1, C1, D1, and E1, EG 2: A2, B2, C2, D2, and E2, EG3: A3, B3, C3, D3, and E3, EG 4: A4, B4, C4, D4, and E4, and EG 5: A5, $\mathrm{B} 5, \mathrm{C} 5, \mathrm{D} 5$, and E5.

5. The students were then asked to return to their Jigsaw groups where each of them explained and presented the structure of the concept map of his assigned section, which was already prepared in his respective expert group.

The Jigsaw technique is visually organized and depicted in the map in Figure 1. Figure 2 illustrates the organization of the Jigsaw and expert groups in the present study. 


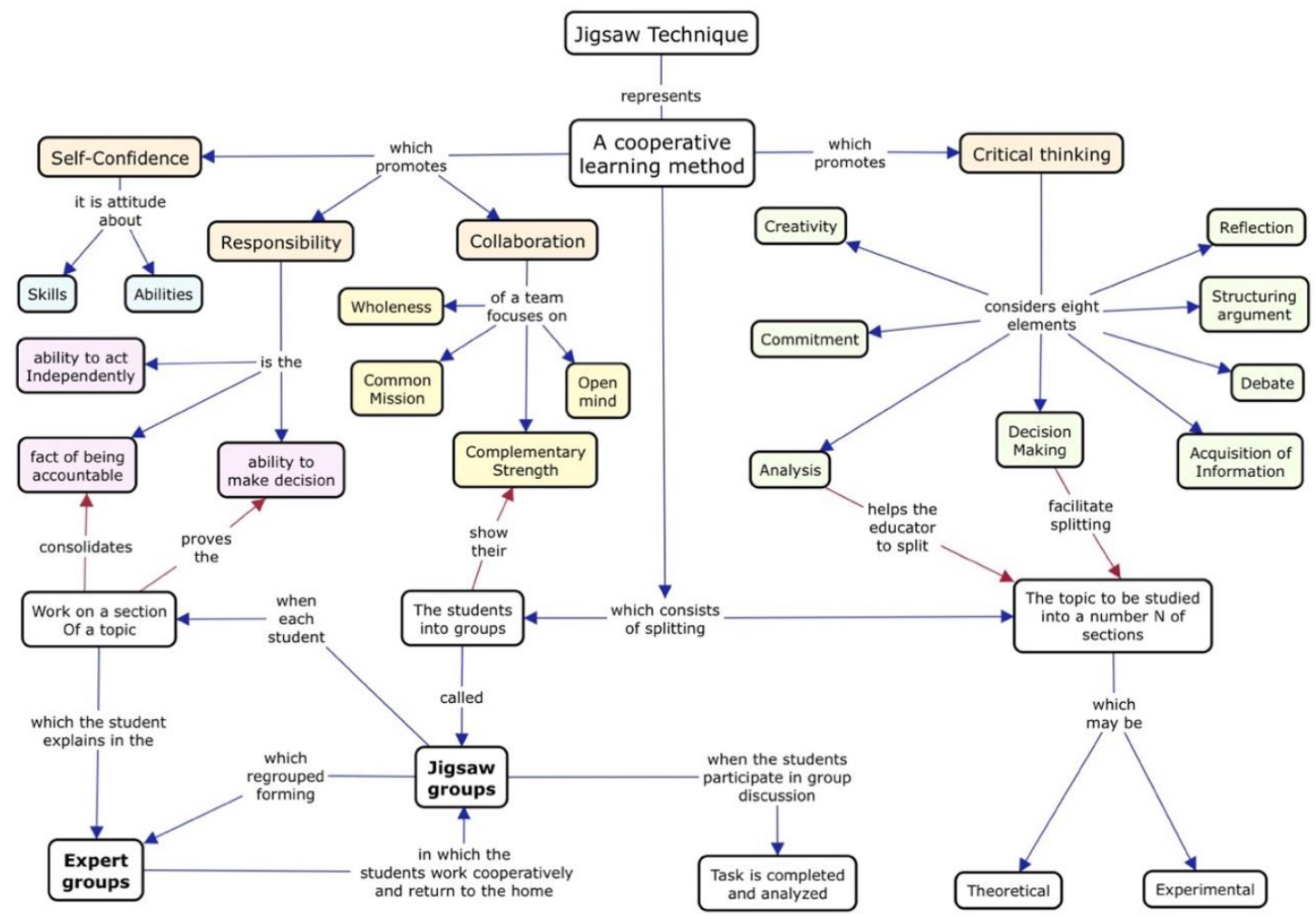

Figure 1: Concept map for the cooperative learning Jigsaw technique, which was constructed by the authors of this study. 


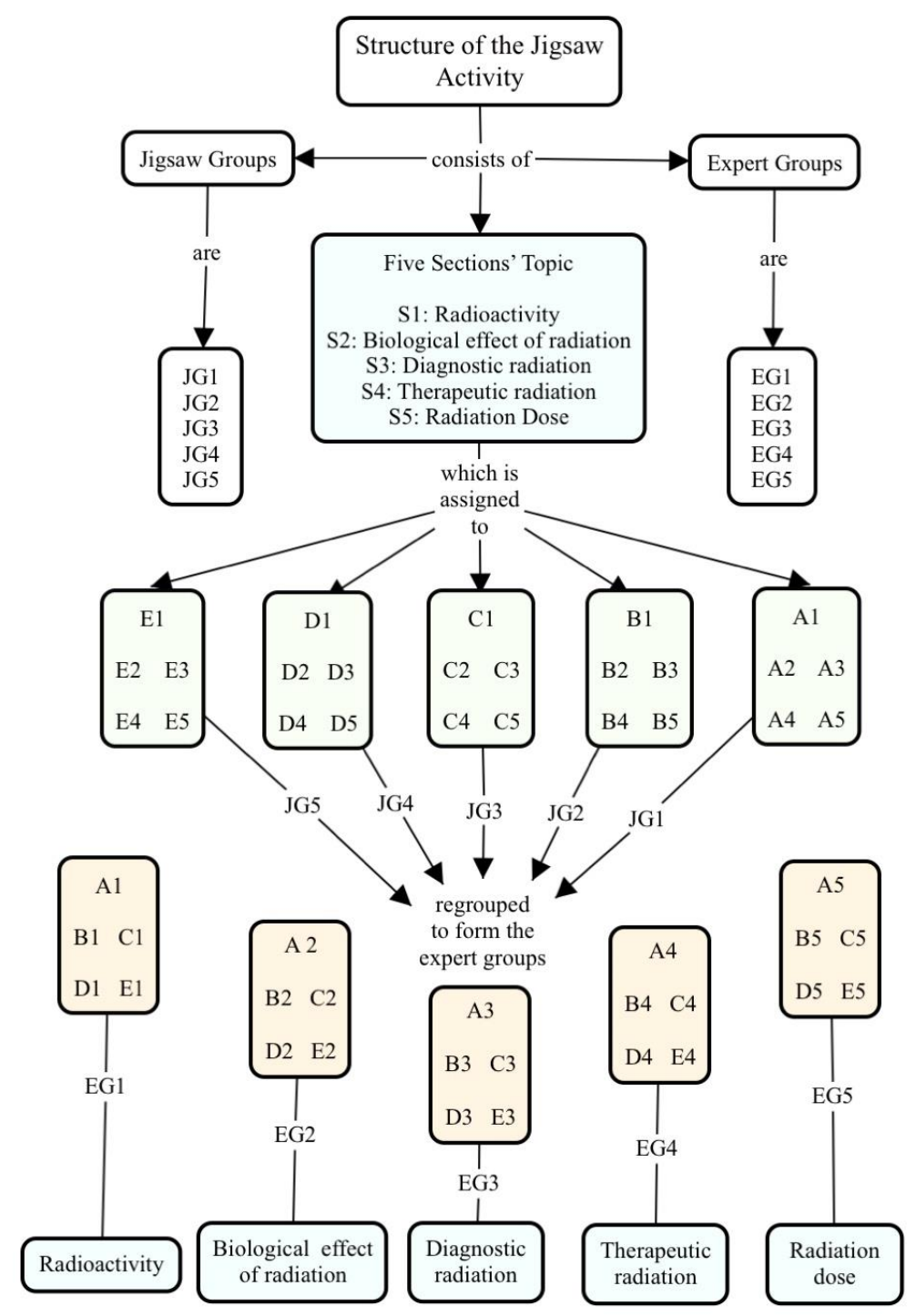

Figure 2: Organization of the Jigsaw and expert groups to map the concepts of nuclear radiation in diagnosis and therapy. It was constructed by the authors of this study

To ensure that the experimental group was well-prepared before conducting the Jigsaw activity, the arrangement of the R-to-GTMs were implemented. A preclass content was uploaded to the e-learning system of IAU. The content consisted of the used textbook (Knight et al., 2019), summarized concepts on nuclear radiation in medicine, selected videos and PhET animations, concept map software (Cmap Tools: version 6.01.01) and the concept map for the Jigsaw cooperative learning technique shown in Figure 1. In the first session, the educator introduced the whole topic interactively and prepared students for the forthcoming activity. It helped the assigned students to be actively engaged with the topic material, purposefully participate in the learning environment, take more responsibility for their performance in the activity, learn how to map the concepts, and apply the physics laws to a real-world problem. In the three active sessions following, the Jigsaw activity was conducted. Two examples on the concept maps, which were constructed and presented by the assigned students in this study, are shown in Figure 3 and Figure 4, respectively. 


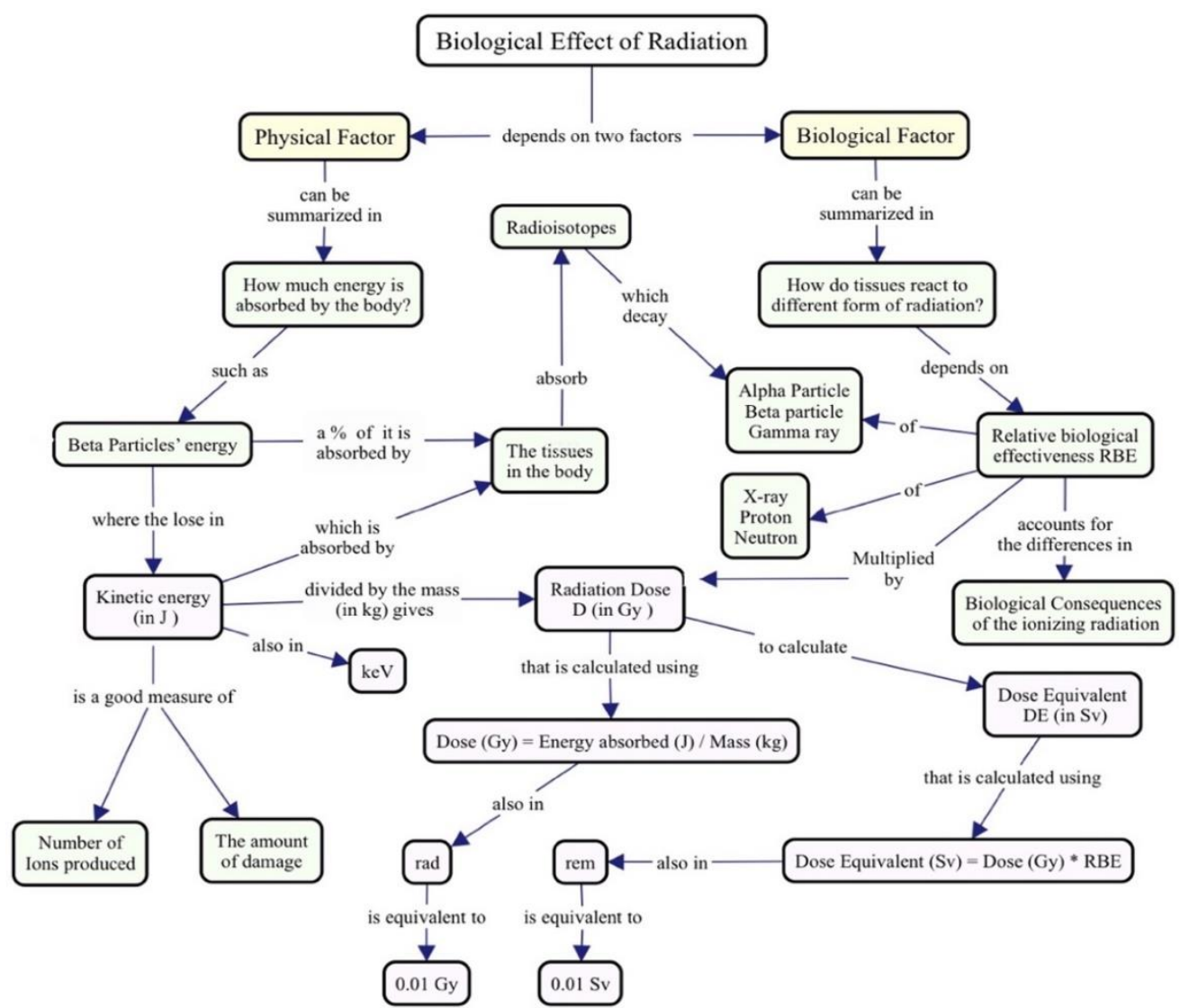

Figure 3: Concept map for the biological effect of radiation. It was constructed by EG2

It is worthwhile to mention that concept map is mainly constructed to answer a particular question. Before constructing the concept map of the biological effect of radiation, which is shown in Figure 3, the students of EG 2 came up with the question "How do tissues react with different forms of nuclear radiation?". They answered the question in five steps. Firstly, selecting the key concepts (e.g., biological factor, physical factor, radioisotopes, radiation dose, and dose equivalent) without linking them. Secondly, choosing the necessary subconcepts (e.g., kinetic energy, relative biological effectiveness, alpha particle-beta particle-gamma ray, mass of body tissues, amount of damage) to be linked with the key concepts. Thirdly, rearranging and interlinking the key concepts and sub-concepts using appropriate words (e.g., absorb, which decays, is a good measure of, can be summarized in, which is absorbed by, etc). For example, "the tissues in the body absorb radioisotopes", "the absorbed kinetic energy is a good measure of the amount of tissue damage", "physical factor can be summarized in how much energy is absorbed by the body?". Fourthly, Using appropriate words to crosslink concepts from the hierarchy that begins with the "physical factor" concept to the one that begins with the "biological factor" concept. For example, "radioisotopes decay alpha particles, beta particles or gamma rays". Finally, Checking the content of the concept map and remove any redundant concept, since the goal of the concept mapping is the process itself rather than the resulting concept map. Following the same procedure, the EG 3 constructed the concept map of the diagnostic radiation (Nuclear imaging), which is shown in Figure 4. 


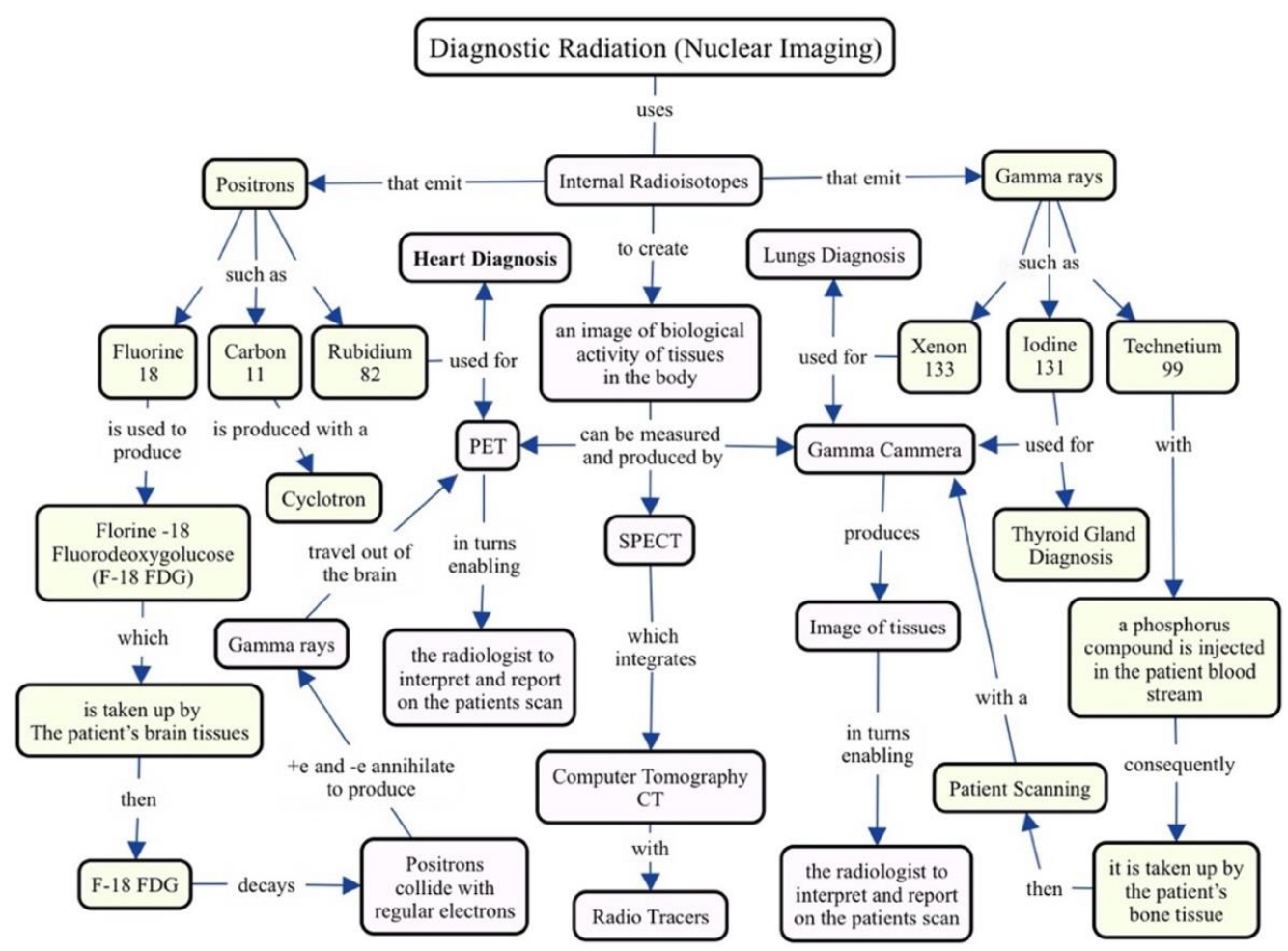

Figure 4: Concept map for diagnostic radiation. It was constructed by EG 3

It was concluded that the well-thought-out topic of the jigsaw activity, nuclear radiation in diagnosis and therapy, motivated the students to brainstorm and generate new ideas, to discover new concepts and the propositions that connect them, to manifestly communicate ideas and information, to integrate new concepts with older concepts, and to gain in-depth comprehension of the topic (José \& Helen, 2013). Additionally, the students took the opportunity to actively assist each other, attain high levels of cognitive performance, and recapitulate concepts using their own words. During the activity, the educator (first author) carefully guided the students, responded to their inquiries, and clarified some concepts when needed. Notably, the constructed concept maps served as a quintessential appraisal tool for the educator to spot students' misconceptions and to evaluate areas in which students had not yet understood concepts extensively (Mustafa \& Talat, 2013). Subsequently, the full concept map for nuclear radiation was constructed in the last interactive session by the students and the educator (first author) as shown in Figure 5. The students were encouraged to consolidate what they had learnt in the Jigsaw groups and expert groups, to discover the relationship between their ideas, to compare viewpoints, find similarities and gauge differences (Maija, 2012). An online Pearson's adaptive follow-up assignment (Pearson, MyLab and Mastering, 2019) was targeted at the students' areas of weakness. It consisted of questions that addressed gaps in understanding based on the students' performance in the concept mapping. After conducting the activity, the experimental and control groups underwent the same post-test. 


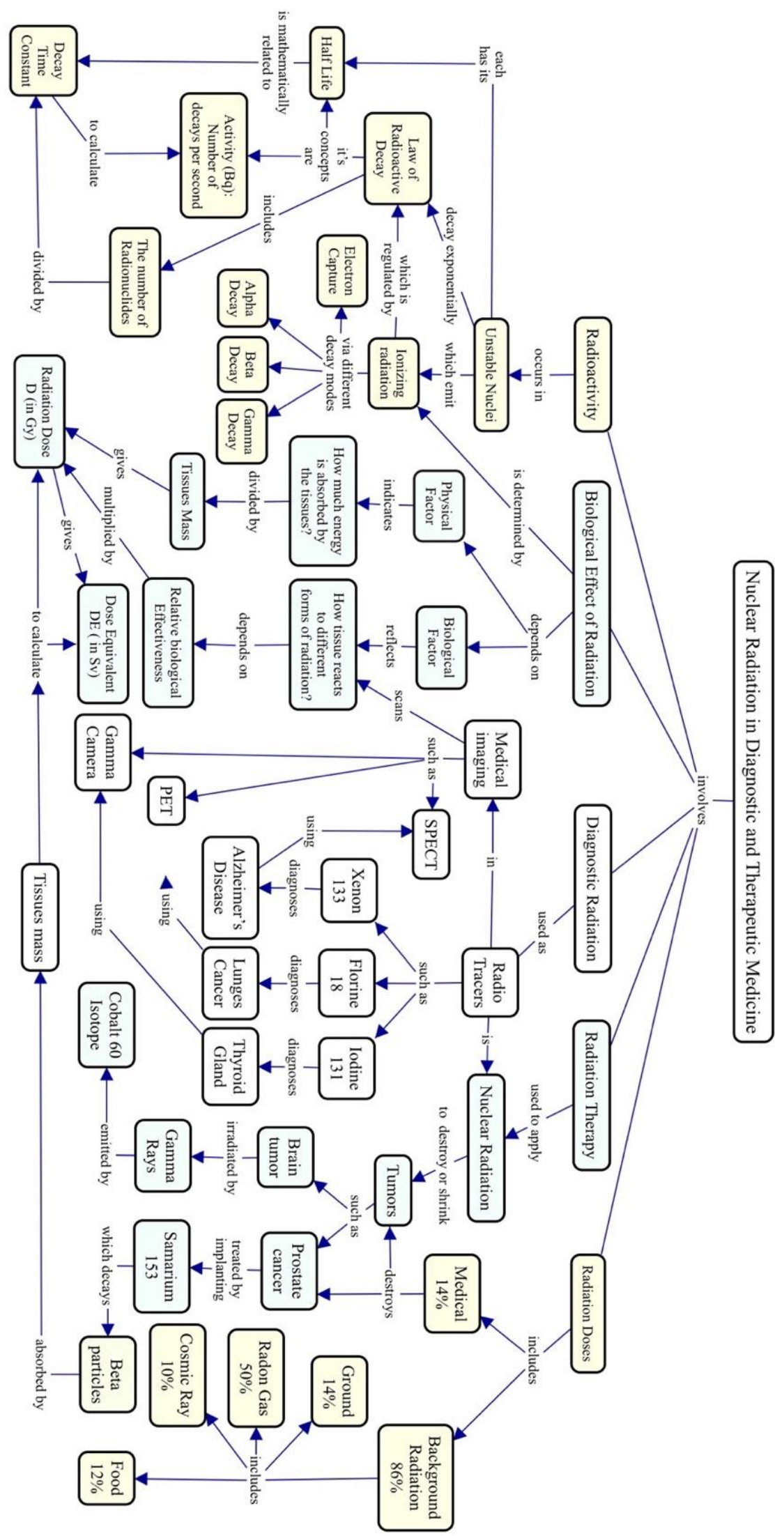

Figure 5: The full concept map for nuclear radiation in diagnosis and therapy. It was constructed by the educator (first author) and the experimental group 


\subsection{Statistical Treatment}

The Statistical Package for the Social Sciences SPSS.20.0 (SPSS Inc, Chicago, IL, USA) was used to analyses the data for the pre-test and post-test for the control and experimental group students; an independent sample t-test and paired sample t-test were used to test the hypotheses of this study (Ju, 2015). The t-tests assume that the data follow a normal distribution or a Gaussian distribution. It is assumed that the population from which the samples are taken is normally distributed. Therefore, in order to check the normality assumption, Shapiro's test was used $(\alpha=0.05)$ (Ghasemi \& Zahedias, 2012). Levene's test (Gastwirth et al., 2009) for equality of variances was also used to determine if the control and experimental groups have about the same or different amounts of variability between scores in the pre-test as well as in the post-test. The independent sample t-test was applied to compare the pre-test scores of the control and experimental groups; the NH_1 was tested. The paired sample $\mathrm{t}$-test was then applied to compare the pre-test and the post-test experimental group scores as well as for the control group scores; NH_2 and NH_3 were tested. Average normalized gains were also calculated for both groups to compare the effectiveness of each teaching method in promoting conceptual understanding and improving the academic achievement level of students in physics (Bao, 2006). To determine the impact of Jigsaw cooperative learning on students' performance in physics, the independent sample t-test was applied once more to compare the post-test scores of the students who were taught using the Jigsaw technique and those who taught through traditional lectures; $\mathrm{NH}_{-} 4$ was tested. Cohen's d effect size (Sawilowsky, 2009; Lakens, 2013) was calculated for independent and paired samples. Moreover, the average normalized gain was calculated (Hake, 1998), which measures the effectiveness of a course in promoting conceptual understanding.

\section{Results and Analysis}

In this section, the results of the study are presented and discussed with reference to the aim of the study. The formulated hypotheses are tested using statistical methods to answer the research question.

\subsection{Normality test and the Research Paradigm}

The Shapiro's test calculates a W-statistic that tests if a random sample comes from a normal distribution. $\alpha=0.05$ is the level of significance used in this study. The test rejects the hypothesis of normality when the P-value is less than or equal to 0.05. Table 3 shows the results of the Shapiro's test, which revealed that the pre-test and the post-test scores of the control and experimental groups follow the normal distribution as the P-value of each is greater than 0.05 . The control and experimental groups for this study were randomly selected from the physics students of the DPY at IAU; consequently, the assumptions of normality and randomization were satisfied.

Table 3: Shapiro's test of normality

\begin{tabular}{|l|c|c|c|}
\hline Students' scores & W-Statistic & df & P-value \\
\hline Pre-test_Experimental & 0.926 & 25 & 0.072 \\
\hline Pre-test_Control & 0.943 & 25 & 0.173 \\
\hline
\end{tabular}




\begin{tabular}{|l|l|l|l|}
\hline Post-test_Experimental & 0.920 & 25 & 0.052 \\
\hline Post-test_Control & 0.948 & 25 & 0.226 \\
\hline
\end{tabular}

The paradigm for this study is shown in Figure 6: t-tests and tested hypotheses.

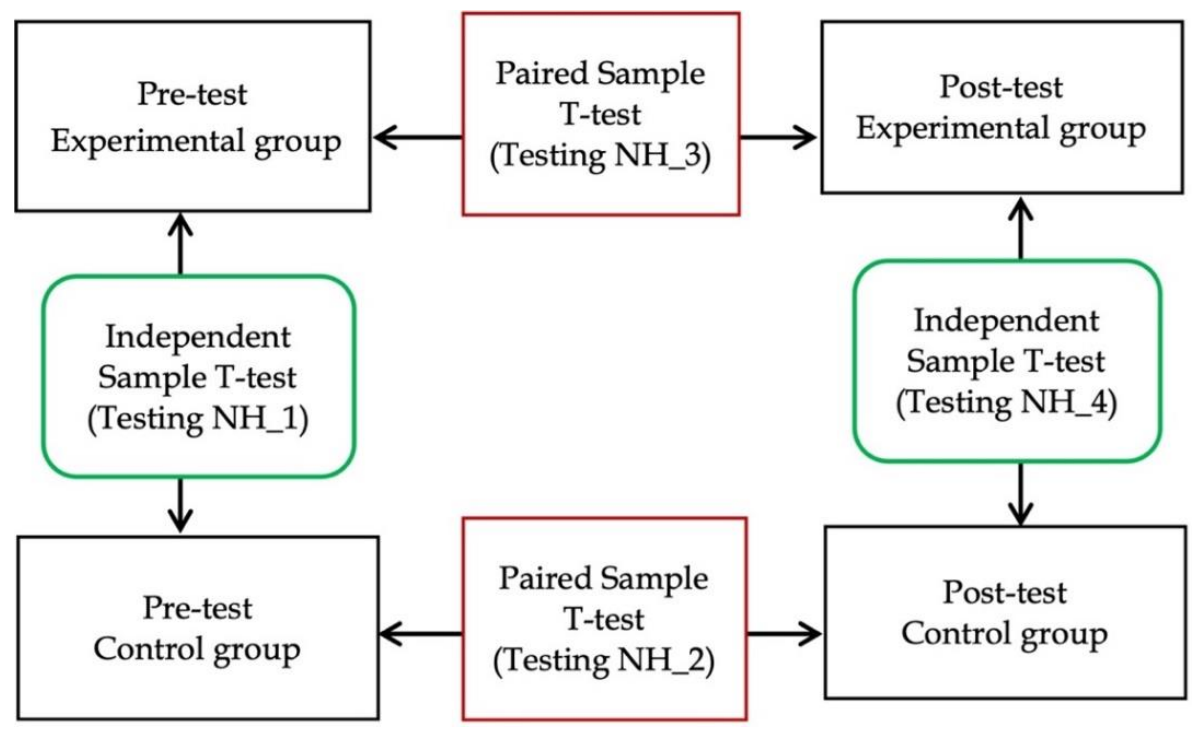

Figure 6: Paradigm for this study: t-tests and tested hypotheses. It was designed by the authors of this study

\subsection{Testing NH_1}

An independent sample test was used to analyze the data for both the experimental and control groups in the pre-test at a level of significance $\alpha=$ 0.05 . The fifty students in the experimental and control groups participated in the pre-test. From Table 4, it is revealed that the experimental group of twentyfive students had a mean score of 6.96 with a standard deviation of 2.12093. The control group of twenty-five students had a mean score of 6.74 with a standard deviation of 1.8491 .

Table 4: Pre-test analysis of the differences in the physics scores between the experimental group and control group using the $t$-test for independent samples

\begin{tabular}{|c|c|c|c|c|c|c|c|c|c|}
\hline Group & \multicolumn{2}{|c|}{ Test } & $\mathbf{N}$ & \multicolumn{2}{|c|}{ Mean } & \multicolumn{2}{|c|}{ Std. Dev. } & \multicolumn{2}{|c|}{$\begin{array}{l}\text { Std. Error } \\
\text { Mean }\end{array}$} \\
\hline Experimental & \multicolumn{2}{|c|}{ Pre-test } & 25 & \multicolumn{2}{|c|}{6.960} & \multicolumn{2}{|c|}{2.12093} & \multicolumn{2}{|c|}{0.42419} \\
\hline Control & \multicolumn{2}{|c|}{ Pre-test } & 25 & \multicolumn{2}{|c|}{6.740} & \multicolumn{2}{|c|}{1.84910} & \multicolumn{2}{|c|}{0.36982} \\
\hline \multicolumn{4}{|c|}{$\begin{array}{l}\text { Levene's test for equality of } \\
\text { variances }\end{array}$} & \multicolumn{6}{|c|}{$\mathrm{t}$-test for equality of means } \\
\hline \multirow[t]{2}{*}{ Variance } & \multirow[t]{2}{*}{$\mathbf{F}$} & \multirow[t]{2}{*}{ Sig. } & \multirow[t]{2}{*}{ df } & \multirow[t]{2}{*}{$\begin{array}{l}\text { Std. Error } \\
\text { Difference }\end{array}$} & \multirow[t]{2}{*}{$\begin{array}{c}\mathrm{t}- \\
\text { statistic }\end{array}$} & \multirow[t]{2}{*}{$\begin{array}{c}\mathrm{P}- \\
\text { value }\end{array}$} & \multicolumn{3}{|c|}{$\begin{array}{l}95 \% \text { Confidence } \\
\text { Interval of the } \\
\text { Difference }\end{array}$} \\
\hline & & & & & & & Lov & & Upper \\
\hline $\begin{array}{l}\text { Equal } \\
\text { variance } \\
\text { assumed }\end{array}$ & \multirow{2}{*}{0.37} & \multirow{2}{*}{0.54} & 48 & 0.56276 & 0.391 & 0.698 & $-0.0 \varsigma$ & & 1.3515 \\
\hline $\begin{array}{l}\text { Equal } \\
\text { variances not } \\
\text { assumed }\end{array}$ & & & 47.1 & 0.56276 & 0.391 & 0.698 & -0.05 & & 1.3520 \\
\hline
\end{tabular}


It is known that Levene's test for equality of variances determines if the two groups have about the same or different amounts of variability between scores in the pre-test. As shown in Table 4, Sig. $>0.05(=0.54)$. This value, greater than 0.05 , means that the experimental and control groups had the same amount of variability between scores in the pre-test and the resulted calculation used pooled variances. Hence, the t-statistic is 0.391 with 48 degrees of freedom. The $\mathrm{P}$-value is 0.698 , which is greater than 0.05 .

Accordingly, the NH_1 cannot be rejected; thus, it is inferred that there is no statistically significant difference between the mean pre-test scores achievement in physics for the experimental and control groups. These results indicate that the two groups were similar in level with regard to their learning competency before conducting the study. A quasi-experimental method was applied by the educator (first author). The experimental group was exposed to the Jigsaw cooperative technique. In contrast, the control group was exposed to a welldesigned sequence of traditional lectures and was not engaged in the cooperative learning activity. The sequences of the Jigsaw activity and the traditional lectures were developed over the course of five classroom sessions as illustrated in Tables 1 and 2.

\subsection{Testing $\mathbf{N H} \_2$ and $\mathbf{N H} \_3$}

A paired sample t-test was used to compare the mean scores of the control group students in the pre-test and post-test. From Table 5, the value of the t-statistic is 6.726 with 24 degrees of freedom, and the P-value is 0.000 , which is much smaller than 0.05. Consequently, NH_2 is rejected; thus, it is inferred that there is a significant improvement in the performance of students who were taught through the well-structured traditional teaching technique. Similar analysis was done to compare the mean scores of the experimental group students in the pretest and post-test; it was found that the t-statistic is 5.081 with 24 degrees of freedom, and the P-value is 0.000 as indicated in Table 6. NH_3 is rejected; thus, it can be concluded that there was a significant improvement of the performance of students who were taught with the Jigsaw cooperative learning technique.

Table 5: Comparison of the mean scores of the control group students using a paired samples t-test

\begin{tabular}{|c|c|c|c|c|c|c|c|c|}
\hline \multicolumn{9}{|c|}{ Paired Sample Statistics / Control Group } \\
\hline Group & Test & $\mathbf{N}$ & \multicolumn{2}{|c|}{ Mean } & \multicolumn{2}{|c|}{ Std. Dev. } & \multicolumn{2}{|c|}{$\begin{array}{l}\text { Std. Error } \\
\text { Mean }\end{array}$} \\
\hline Control & Post-test & 25 & \multicolumn{2}{|c|}{8.0440} & \multicolumn{2}{|c|}{1.29037} & \multicolumn{2}{|c|}{0.25807} \\
\hline Control & Pre-test & 25 & \multicolumn{2}{|c|}{6.7400} & \multicolumn{2}{|c|}{1.84910} & \multicolumn{2}{|c|}{0.36982} \\
\hline \multicolumn{9}{|c|}{ Paired Sample t-test Results / Control Group } \\
\hline Test & Mean & $\begin{array}{l}\text { Std. } \\
\text { Dev. }\end{array}$ & $\begin{array}{c}\mathrm{t}- \\
\text { statistic }\end{array}$ & df & $\begin{array}{c}\text { P- } \\
\text { value }\end{array}$ & \multicolumn{3}{|c|}{$\begin{array}{l}95 \% \text { Confidence } \\
\text { Interval of the } \\
\text { Difference }\end{array}$} \\
\hline Post-test_Control & \multirow{2}{*}{1.3040} & \multirow{2}{*}{0.9693} & \multirow{2}{*}{6.726} & \multirow{2}{*}{24} & \multirow{2}{*}{0.000} & \multirow{2}{*}{\multicolumn{2}{|c|}{$\begin{array}{c}\text { Upper } \\
0.90389\end{array}$}} & Lower \\
\hline Pre-test_Control & & & & & & & & 1.7041 \\
\hline
\end{tabular}


Table 6: Comparison of the mean scores of the experimental group students using a paired samples t-test

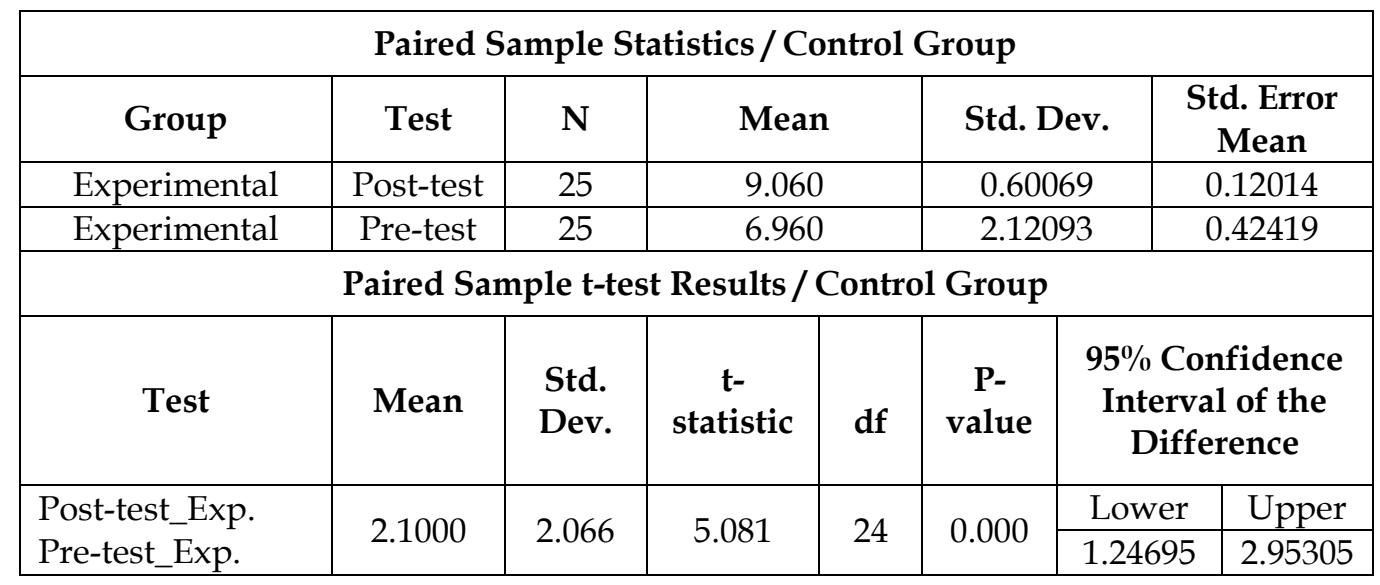

The results of the paired sample t-tests were used to determine the effect size by calculating Cohen's d (Sawilowsky, 2009). It is based on the following interpretation for Cohen's d: 0.2 (small effect size), 0.5 (medium effect size) and 0.8 (large effect size). Since we are dealing with small sample sizes in this study, we applied the corrected Cohen's d formula (Lakens, 2013):

$$
\mathrm{d}=\frac{\mathrm{M}_{\mathrm{E}}-\mathrm{M}_{\mathrm{C}}}{\sqrt{\left(\mathrm{SD}_{1}{ }^{2}+\mathrm{SD}_{2}{ }^{2} / 2\right)}}\left(\frac{\mathrm{N}-3}{\mathrm{~N}-2.25}\right) \sqrt{\frac{\mathrm{N}-2}{\mathrm{~N}}}
$$

where $\mathrm{M}_{\mathrm{E}}, \mathrm{M}_{\mathrm{C}}, \mathrm{SD}_{1}$, and $\mathrm{SD}_{2}$ are the mean of the experimental group, the mean of the control group, the standard deviation of the experimental group and the standard deviation of the control group, respectively.

The average normalized gain was introduced by Hake (1998) as a measure of the effectiveness of a course in promoting conceptual understanding. He defined the average normalized gain as:

$$
<\text { g }>=\frac{<\text { Post }- \text { Test }>-<\text { Pre-Test }>}{10-<\text { Pre-Test }>}
$$

where brackets indicate class average scores out of 10 . This measure is generally described as the amount students learned divided by the amount they could have learned. The average normalized gain was used to determine the assessment of the students in terms of their scores using the following interpretation: $0-30 \%$ (Low Gain), 31\% -70\% (Medium Gain) and 71\% -100\% (High Gain).

Table 7: Effect size calculation from the paired sample t-test output, and the average

\begin{tabular}{|c|c|c|c|c|c|c|}
\hline Students' scores & $\mathbf{N}$ & Mean & Std. Dev. & t-statistic & Cohen's d & $\begin{array}{c}\text { Normalized } \\
\text { Gain }<\mathrm{g}>\end{array}$ \\
\hline Post-test_Exp. & \multirow{2}{*}{25} & 9.0600 & \multirow{2}{*}{2.06660} & \multirow{2}{*}{5.081} & \multirow{2}{*}{1.016} & \multirow{2}{*}{0.69} \\
\hline Pre-test_Exp. & & 6.9600 & & & & \\
\hline Post-test_Control & \multirow{2}{*}{25} & 8.0440 & \multirow{2}{*}{0.96931} & \multirow{2}{*}{6.726} & \multirow{2}{*}{1.345} & \multirow{2}{*}{0.40} \\
\hline Pre-test_Control & & 6.7400 & & & & \\
\hline
\end{tabular}
normalized gain 
As shown in Table 7, the effect size was large (Cohen's $d>0.8$ ) for both groups indicating an improvement in the students' achievement for both the experimental and control groups, namely 1.016 for the experimental group and 1.345 for the control group. The interpretation of these results is in the line with the study of Abdul Hadi (2014) who concluded that learning physics requires following the textbook and the information delivered by the educator in the class to gain conceptual knowledge, which enables them to assess and analyze real-world physics problems that promote their thinking to higher levels. Thus, the control group students still need to learn through the traditional lectures that are structured using the arrangement of the R-to-GTMs. It is worth mentioning that the difference in the normalized gain between the experimental and the control group strongly differentiates between the learning techniques, allowing the educator (first author) to compare his students' learning to those of other students (Hake, 1998). However, the normalized gain was significantly higher for the experimental group which gained $0.69(69 \%)$, than for the control group, which gained $0.40(40 \%)$. Based on this finding, it can be concluded that effective group work, such as that enabled by the Jigsaw technique, can enhance the positive attitude and performance of students in learning medical physics concepts. This conclusion is supported by the study of Gamabri and Yusuf (2014) who reported that students demonstrated better performance when taught through cooperative learning than the traditional method of teaching. Furthermore, the study of Yemi and Azid (2018) revealed that the Jigsaw technique contributed effectively to improving students' achievement, fostering their interest in learning, and enhancing their communication skills.

\subsection{Testing the NH_4}

The independent sample t-test was applied one more time to analyze the data for both the experimental and control groups in the post-test at a level of significance $\alpha=0.05$. From Table 8 , it can be concluded that the experimental group had a mean score of 9.060 with a standard deviation of 0.60069 , and the control group had a mean score of 8.044 with a standard deviation of 1.29037.

Table 8: Post-test analysis of differences in the physics scores between the experimental group and control group using $t$-test for independent samples

\begin{tabular}{|c|c|c|c|c|c|c|c|c|}
\hline Group & \multicolumn{2}{|c|}{ Test } & $\mathbf{N}$ & \multicolumn{2}{|c|}{ Mean } & Std. Dev. & \multicolumn{2}{|c|}{$\begin{array}{l}\text { Std. Error } \\
\text { Mean }\end{array}$} \\
\hline Experimental & \multicolumn{2}{|c|}{ Post-test } & 25 & \multicolumn{2}{|c|}{9.060} & 0.60069 & \multicolumn{2}{|c|}{0.12014} \\
\hline Control & \multicolumn{2}{|c|}{ Post-test } & 25 & \multicolumn{2}{|c|}{8.044} & 1.29037 & \multicolumn{2}{|c|}{0.25807} \\
\hline \multicolumn{4}{|c|}{$\begin{array}{c}\text { Levene's test for equality of } \\
\text { variances }\end{array}$} & \multicolumn{5}{|c|}{ t-test for equality of means } \\
\hline \multirow[t]{2}{*}{ Variance } & \multirow[t]{2}{*}{ F } & \multirow[t]{2}{*}{ Sig. } & \multirow[t]{2}{*}{ df } & \multirow[t]{2}{*}{$\begin{array}{l}\text { Std. Error } \\
\text { Difference }\end{array}$} & \multirow[t]{2}{*}{$\begin{array}{c}\mathrm{t}- \\
\text { statistic }\end{array}$} & \multirow[t]{2}{*}{$\begin{array}{c}\mathrm{P}- \\
\text { value }\end{array}$} & \multicolumn{2}{|c|}{$\begin{array}{l}\text { 95\% Confidence } \\
\text { Interval of the } \\
\text { Difference }\end{array}$} \\
\hline & & & & & & & Lower & Upper \\
\hline $\begin{array}{l}\text { Equal variance } \\
\text { assumed }\end{array}$ & \multirow[b]{2}{*}{9.34} & \multirow[b]{2}{*}{0.004} & 48 & 0.28467 & 3.569 & 0.001 & 0.4436 & 1.5883 \\
\hline $\begin{array}{l}\text { Equal } \\
\text { variances not } \\
\text { assumed }\end{array}$ & & & 33.9 & 0.28467 & 3.569 & 0.001 & 0.4374 & 1.5945 \\
\hline
\end{tabular}


As shown in Table 8, Levene's test gives Sig. $<0.05(=0.004)$, revealing that the experimental and control groups do not have the same amount of variability between scores in the post-test, and the calculation utilizes un-pooled variances and a correction to the degrees of freedom. Hence, the t-statistic is 3.569 with 33.9 degrees of freedom. The P-value is 0.001 , which is smaller than 0.05 . Consequently, NH_4 is rejected, leading us to conclude that there is a statistically significant difference between the mean post-test scores in physics for the experimental and control groups. The output of the independent sample t-test was used to calculate the effect size. The calculations are given in Table 9. The results demonstrate a small effect size for the pre-test scores (Cohen's $\mathrm{d}=$ 0.1108 ) and a large effect size for the post-test scores (Cohen's $d=0.9931$ ) for the experimental and control groups. Thus, we can conclude that the students were performing equally in the pre-test while students in the experimental group performed better than those in the control group in the post-test. On that account, the experimental group performed significantly better than the control group on the post-test. Consequently, the answer to research question is 'Yes. The application of the Jigsaw cooperative learning technique is effective in improving first-year medical students' academic achievement in physics.'

Table 9: Calculating effect size (Cohen's d) from independent sample t-test output

\begin{tabular}{|l|c|c|c|c|}
\hline \multicolumn{1}{|c|}{ Students' scores } & N & Mean & Std. Deviation & Cohen's d \\
\hline Pre-test_Experimental & 25 & 6.960 & 2.12093 & \multirow{2}{*}{0.1108} \\
\hline Pre-test_Control & 25 & 6.740 & 1.84910 & \\
\hline Post-test_Experimental & 25 & 9.060 & 0.60069 & \multirow{2}{*}{0.9931} \\
\hline Post-test_Control & 25 & 8.044 & 1.29037 & \\
\hline
\end{tabular}

Our findings are in the line with previous studies. Aydin \& Biyikli (2017) highlighted that the superiority of the Jigsaw technique lies in enhancing the students' learning experience, provoking their interest in studying physics, and producing a healthy atmosphere of collaboration between the students and the educator. Shahri et al. (2017) stated that time constraints represent one of the challenges of using the Jigsaw technique. Since implementing Jigsaw activities in a class can be time-consuming, proper time management by the educator is essential. Rahul and Abdul Sattar (2016) recommended that a didactic lecturebased learning technique ought to be replaced by a cooperative learning technique such as Jigsaw to encourage learning among medical students. Abd El Aliem et al. (2019) concluded that Jigsaw is an unconventional technique that enhanced the achivenment of nursing students, and it can be widely implmented in nursing education to promote the nursing students' skills. Furthermore, the findings of numerous educational studies support the present study in concluding that Jigsaw cooperative learning has a significant positive effect on students' academic achievement (Maija, 2012; Martínez et al., 2012; Mustafa \& Talat, 2013; Isiaka \& Mudasiru, 2016; Bharti et al., 2017; Kumar et al., 2017; Pelobillo, 2018; Amiruddin et al., 2019; Ephraim et al., 2019).

\section{Conclusion}

The pedagogical studies have fundamentally proven that cooperative learning activities promote the students' thinking skills to higher levels and encourage them to put the facts together in novel ways. The result of this study supports 
the findings of the previous studies and emphasizes the effectiveness of using the Jigsaw cooperative learning technique in promoting first-year medical students' academic achievement in physics. A quasi-experimental approach with a pretest-posttest design was employed to conduct the study. The experimental group was exposed to the Jigsaw cooperative technique. In contrast, the control group was exposed to a well-designed sequence of traditional lectures and was not engaged in the cooperative learning activity. The effect size was large for experimental and control groups indicating an improvement in the students' achievement for both the experimental and control groups. However, the normalized gain was significantly higher for experimental group than that for control group. The experimental group students had the opportunity to organize their thoughts and debate their opinions, by working in small groups towards the common goal: Mapping the concept of nuclear radiation in diagnosis and therapy. In conclusion, the Jigsaw activity increased the students' engagement level and allowed them to analyze and assess the validity of facts, generate ideas in terms of how the concepts for the studied topic can be mapped and applied to biomedical cases. Furthermore, it motivated the first-year medical students to make progress in terms of organizing and understanding new information in physics and enabled them to keep up with their cognitive development. The jigsaw activity required sufficient time to be prepared and implemented; nonetheless, it strengthened the social relationships among the students in both the Jigsaw groups and the expert groups.

\section{Limitations}

Since Jigsaw is a time-consuming cooperative learning technique, two expert groups in this study couldn't complete their assigned concept maps within the assigned time. It is highly recommended that thoughtful educators in medical physics pay extra attention to the time needed to implement Jigsaw activities successfully and appropriately. Sufficient time enables the educator to significantly guide all Jigsaw group dynamics and support the tasks, which are the responsibility of each individual group member.

\section{Recommendations for Future Research}

Future studies have been proposed by the authors of this study.

- A follow-up study could be conducted to take the feedback of the students, the experimental group of the present study, about the use of concept mapping tool in learning advanced medical topics in their study fields. The study could answer the following question: "Is the application of concept mapping functional in analyzing advanced medical cases?"

- A well-structured online model could be developed, especially during the Covid-19 pandemic, to study the effect of using the Jigsaw technique on students' perception of a multidisciplinary topic: the action-potential of a nerve cell. Particularly, seeking for an answer to the question: "does teaching a multidisciplinary topic require using innovative active learning method?".

- Attempts to shed light on the effectiveness of the Jigsaw II technique on students' achievement in medical physics could be crystalized into assessing and analyzing biomedical cases on the viscosity of blood. Specifically, going 
for an answer to the question: "does well-organized classroom activity make students depend on each other to comprehend an advanced medical physics topic?".

\section{Acknowledgement}

The authors would like to thank the DPY at IAU for continuous support and the students for their effective participation during the course of this study.

\section{References}

Abd El Aliem, R. S., Sabry, S. S., \& Mohy El-Deen, H. F. (2019, December 27). Utilization of Jigsaw Cooperative Learning Strategy on Maternity Nursing Students' Attitude and Achievement. American Journal of Nursing Science, 8(6), 361-370. http://doi.org/10.11648/j.ajns.20190806.22

Abdul Hadi, L. B. (2014). Investigating Metacognitive Awareness and Self-Efficacy of High School Students through Prompted Reflections in Mathematics and Science. The British University in Dubai. http://bspace.buid.ac.ae/handle/1234/675

Aliya, N., Shilpashree, Y. D., Namitha, D., Rajeshwari, A., Asharani, N., \& Rafiya, B. (2019, Feb). Jigsaw Classroom: Is it an Effective Method of Teaching and Learning? Students' Opinions and Experience. Journal of Clinical and Diagnostic Research, 13(2), 1-4. http:// doi.org/10.7860/JCDR/2019/39613.12540

Alraddadi, A. (2010). The Effects of Cooperative Learning Experiences on Achievement, Attitudes, and Behaviours in Biology. Department of Biological Sciences, University of Limerick. http://hdl.handle.net/10344/9535

Amiruddin , K. I., Nyoman, S. D., \& Muhammad, N. A. (2019, October). Effect of Jigsaw Strategy and Learning Style to Conceptual Understanding on Senior High School. International Journal of Emerging Technologies in learning (IJET), 14(19), 414. https://doi.org/10.3991/ijet.v14i19.11592

Angell, C., Guttersrud, Ø., Henriksen, E. K., \& Isnes. (2004, June). Physics: Frightful, but fun. Pupils' and teachers' views of physics and physics teaching. Science Education, 88(5), 683-706. https://doi.org/10.1002/sce.10141

Aronson, E., Stephin, C., Stikes, J., Blaney, N., \& Snapp, M. (1978). The Jigsaw Classroom. CA, USA: Beverly Hills, CA, USA: SAGE Publications.

Asoodeh, M. H., Asoodeh , M. B., \& Zarepour , M. (2012). The impact of student centered learning on academic achievement and social skills. Procedia - Social and Behavioral Sciences, 46, 560-564. https://doi.org/10.1016/j.sbspro.2012.05.160

Aydin, A., \& Biyikli, F. (2017). The Effect of Jigsaw Technique on the Students' Laboratory Material Recognition and Usage Skills in General Physics Laboratory-I Course. Universal Journal of Educational Research , 5(7), 1073-1082. https://doi.org/10.13189/UJER.2017.050701

Bao, L. (2006, October). Theoretical comparisons of average normalized gain calculations. Physics Edication Research, 74(10), 917-922. https://doi.org/10.1119/1.2213632

Bharti, B., Bharati, M., Manisha, M., \& Yogenndra , R. S. (2017). Jigsaw Method: An Innovative Way of Cooperative Learning in Physiology. Indian J Physio Pharmaco, 61(3), 315-321. https://www.ijpp.com/IJPP\%20archives/2017_61_3/315-321.pdf

Baliga, S. S., Walvekar, R. B., \& Mahantshetti, J. G. (2021, July). Concept map as a teaching and learning tool for medical students. Journal of Education and Health Promotion, 10(1), 1-6. http://doi.org/10.4103/jehp.jehp_146_20 
Brady, M., \& O'Reilly, N. (2020, April 2020). Learning management systems and their impact on academic work. Technology, Pedagogy and Education, 29(3), 251-268. https://doi.org/10.1080/1475939X.2020.1743746

Chiou, C. (2008, October 10). The effect of concept mapping on students' learning achievements and interests. Innovations in Education and Teaching International, 45(4), 375-387. https://doi:10.1080/14703290802377240

Collins, B., \& Nyenhius, R. (2020, June 19). The Effectiveness of Concept Maps for Students' Learning and Retention. Journal of Political Science Education. https:// doi.org/10.1080/15512169.2020.1775090

Connell, G. L., Donovan, D. A., \& Chambers, T. G. (2016). Increasing the Use of StudentCentered Pedagogies from Moderate to High Improves Student Learning and Attitudes about Biology. CBE-Life Sciences Education, 15, 1-15. https://doi.org/10.1187/cbe.15-03-0062

Deepali, A., \& Neeta, S. (2020). Jigsaw Cooperative Learning: A Vible Teaching Learning Strategy in Ayurveda. An International Journal of Research in AYUSH and Allied Systems, 7(1), 69-73. https://doi.org/10.47070/ayushdhara.v7iSupply1.639

Dong, Y., Wu, S. X., Wang, W., \& Peng, H. (2019, November 27). Is the Student-Centered Learning Style More Effective Than the Teacher-Student Double-Centered Learning Style in Improving Reading Performance? Educational Psychology, a section of the journal Frontiers in Psychology, 10(2630), 1-10. https:// doi.org/10.3389/fpsyg.2019.02630

Eachempati, P., Kiran, K. K., \& Hj Ismail, A. R. (2017, June 1). Cooperative learning through Jigsaw classroom technique for designing cast partial dentures - a comparative study. MedEdPublish, 6(2), 1-14. https:// doi.org/10.15694/mep.2017.000088

Ephraim, J., Dorcas, P., \& Esther, M. (2019). Effects of Jigsaw Cooperative Learning Strategy on Senior Secondary Two Chemistry Students' Understanding of Chemical Kinetics in Jos South LGA of Plateau State, Nigeria. East African Scholars Journal of Education, Humanities and Literature, 2(5), 280-288. https://doi.org/10.36349/easjehl.2019.v02i05.005

Gamabri, I., \& Yusuf, O. M. (2014). Effects of Three Cooperative Learning Strategies on the Performance of Secondary School Students in Physics. Chemistry: Bulgarian Journal of Science Education, 23(3), 1-23. https:// www.academia.edu/8049225

Gamit, A. D., Antolin, J. A., \& Gabriel, A. G. (2017). The Effects of Cooperative Learning in Enhancing the Performance Level of Grade-10 Mathematics Students in Talavera National High School in the Philippines. Journal of Applied Mathematics and Physics, 5(1), 2386-2401. https://doi.org/10.4236/jamp.2017.512195

Ghasemi, A., \& Zahediasl, S. (2012). Normality Tests for Statistical Analysis: A Guide for Non-Statisticians. International Journal of Endocrinology Metabolism, 10(2), 486-489. https://doi.org/10.5812/ijem.3505

Gastwirth, J. L., Gel, Y. R., \& Miao, W. (2009). The Impact of Levene's Test of Equality of Variances on Statistical Theory and Practice. Statistical Science, 24(3), 343-460. https://doi.org/10.1214/09-STS301

Gelu, M., \& Muza, M. (2011). The strengthen knowledge of atomic physics using the "mosaic" method (The Jigsaw method). Procedia Social and Behavioral Sciences, 15(2011), 1605-1610. https://doi.org/10.1016/j.sbspro.2011.03.338

Hake, R. (1998). Interactive-engagement versus traditional methods: A six-thousandstudent survey of mechanics test data for introductory physics courses. Citation: American Journal of Physic, 66, 64-74. https://doi.org/10.1119/1.18809

Isiaka, A. G., \& Mudasiru, O. Y. (2016). Effects of Computer-Assisted Jigsaw II Cooperative Learning Strategy on Physics Achievement and Retention. 
Contemporary $\quad$ Educational,
https://doi.org/10.30935/cedtech/6181

$7(4)$,

$4352-367$

José, A., \& Helen , M. (2013, May). Migrating Successful Student Engagement Strategies Online: Opportunities and Challenges Using Jigsaw Groups and Problem-Based Learning. MERLOT Journal of Online Learning and Teaching, 9(1), 90-105. https://digitalcommons.uri.edu/nrs_facpubs/42/

Jones, K., \& Jones, J. (2008). Making Cooperative Learning Work in the College Classroom: An Application of the 'Five Pillars' of Cooperative Learning to PostSecondary Instruction. The Journal of Effective Teaching, 8(2), 61-76. https:/ / eric.ed.gov/?id=EJ1055588

Ju, K. T. (2015, December). T-test as a parametric statistic. Korean Journal of Anesthesiology, 68(6), 540-546. https://doi.org/10.4097/kjae.2015.68.6.540

Karacop, A. (2017). The Effects of Using Jigsaw Method Based on Cooperative Learning Model in the Undergraduate Science Laboratory Practices. Universal Journal of Educational Research, 5(3), 420-434. http://doi.org/10.13189/ujer.2017.050314

Karacop, A., \& Doymus, K. (2013). Effects of Jigsaw Cooperative Learning and Animation Techniques on Students' Understanding of Chemical Bonding and Their Conceptions of the Particulate Nature of Matter. Journal of Science Education and Technology, 22(2), 186-2003. https://doi.org/10.1007/s10956-012-9385-9

Kemerink, M., Dierichs, T., Dierichs, J., Huynen, H., Wildberger, J., Engelshove, A. J., \& Kemerink, G. (2012, April). The Application of X-Rays in Radiology: From Difficult and Dangerous to Simple and Safe. Medical Physics and Informatics, 198(1), 754-659. https:// doi.org/10.2214/AJR.11.7844

Kim, N. J. (2017, May). Enhancing Students' Higher Order Thinking Skills through Computer-based Scaffolding in Problem-based Learning. 1-252. https://digitalcommons.usu.edu/etd/5488

Knight, R., Jones, B., \& Field, S. (2019). College Physics: A Strategic Approach, Global Edition. San Francisco: Pearson/Addison Wesley.

Kumar, C. V., Suneeta, K., Satish, P., Kumar, R. K., Taj, K. S., Jayasimha, V., Thomas , C. (2017). Effect of Jigsaw Co-Operative Learning Method in Improving Cognitive Skills among Medical Students. International Journal of Current Microbiology and Applied Sciences, 6(3), 164-173. https://doi.org/10.20546/ijcmas.2017.603.001

Lakens, D. (2013, November). Calculating and reporting effect sizes to facilitate cumulative science: A practical primer for t-tests and ANOVAs. Frontiers in Psychology, 4, 1-12. https:// doi.org/10.3389/fpsyg.2013.00863

Lodish, H., Berk, A., Zipursky, S. L., Matsudaira, P., Baltimore, D., \& Darnell, J. (2000). Molecular Cell Biology. New York: W. H. Freeman.

Maija, N. (2012, January). Physics concept maps: Analysis on coherent knowledge structures in physics teacher education. University of Helsinki. http://ethesis.helsinki.fi

Martínez, G. , Pérez, L. Á., Isabel, M., \& Pardo , P. (2013). The Effectiveness of Concept Maps in Teaching Physics Concepts Applied to Engineering Education: Experimental Comparison of the Amount of Learning Achieved With and Without Concept Maps. Journal of Science Education and Technology, 22, 204-2014. https:// doi.org/10.1007/s10956-012-9386-8

Márquez, L. T., Llinás, J. G., \& Macías, F. S. (2017, February). Collaborative Learning: Use the Jigsaw Technique in Mapping Concepts of Physics. Problems of Education in the 21st Century, 75(1), 92-101. https://doi.org/10.33225/pec/17.75.92

McCabe, A., \& O'Connor, U. (2013, November 22). Student-centred learning: The role and responsibility of the lecturer. Teaching in Higher Education, 19, 350-359. https://doi.org/10.1080/13562517.2013.860111 
Mulhall, P. J., \& Gunstone, R. (2007, August). Views about Physics held by Physics Teachers with Differing Approaches to Teaching Physics. Research in Science Education, 38, 435-462. https://doi.org/10.1007/s11165-007-9057-6

Mustafa , K., \& Talat , A. (2013). Effects of Teaching Chemistry Using Concep Maps on Students' Achivement in School Chemistry in India and Turkey. Electronic $\begin{array}{llll}\text { journal of education } & \text { sciences, } & \text { 2(2), } & \text { 14-39. }\end{array}$ https://dergipark.org.tr/tr/download/article-file/147686

Ozdemir, O., \& Öner, E. I. (2015, November). The Effects of Simulations and Animations on Students' Motivation in a Computer Course. Participatory Educational Research, 2015(2), 53-59. http://dx.doi.org/10.17275/per.15.spi.2.7

Pearson. (2019). MyLab and Mastering. https://www.pearson.com

Pelobillo, G. (2018, March). Jigsaw Technique in Learning Physics and Problem-solving Dimensions of Senior High School Students. JPAIR Multidisciplinary Research, 32(1), 90-109. https://doi.org/10.7719/jpair.v32i1.577

Rahul, R., \& Abdul Sattar, K. (2016, December). Jigsaw technique: An interactive approach to sensitize medical students in Saudi Arabia about type 2 diabetes mellitus. Journal of Education Technology in Health Sciences, 3(3), 107-110. http://doi.org/10.18231/2393-8005.2016.0005

Redish, E., \& Steinberg, R. (1999, January). Teaching Physics: Figuring Out What Works. Physics Today, 52(1), 24-30. https:// doi.org/10.1063/1.882568

Redish, E. F. (1994). The Implications of Cognitive Studies for Teaching Physics. American Journal of Physics, 62(6), 796-803. https://doi.org/10.1119/1.17461

Sawilowsky, S. (2009, November 1). New Effect Size Rules of Thumb. Journal of Modern $\begin{array}{llll}\text { Applied Statistical } & \text { Methods, }\end{array}$ https://doi.org/10.22237/jmasm/1257035100

Shahri, M. J., Matlabi, M., Esmaeili, R., \& Kianmehr, M. (2017). Effectiveness of teaching: Jigsaw technique vs. lecture for medical students' Physics course. Bali Medical Journal (Bali Med J), 6(3), 2302-2914. https://doi.org/10.15562/bmj.v6i3.400

Yatimah, D., Solihin, S., Adman, A., \& Syah, R. (2020, October). Jigsaw learning model base on cooperative instructional strategies to improve academic discussion in adult education on environment concepts. Annual Applied Science and Engineering Conference. 1402(033039), 1-4. Journal of Physics: Conference Series. https://doi.org/10.1088/1742-6596/1402/3/033039

Yemi, M. T., \& Azid, B. N. (2018). Effect of Jigsaw Strategy of Cooperative Learning on Mathematics Achivement Among Secondery Schools students. European Journal of Education Studies, 4(2). http:// doi.org/10.5281/zenodo.1167888

Yeong, C.-H., Cheng, M.-H., \& NG, K.-H. (2014, September 25). Therapeutic radionuclides in nuclear medicine: Current and future prospects. Journal of Zhejiang University-SCIENCE B (Biomedicine \& Biotechnology), 15(10), 845-863. https://doi.org/10.1631/jzus.B1400131

Zafer, T., \& Mustafa, E. (2008, May). Effects of Cooperative Learning on Instructing Magnetism: Analysis of an Experimental Teaching Sequence. Lat. Am. J. Phys. Educ., 2(2), 124-136. http://lajpe.org/may08/05_Zafer_Tanel.pdf 